\title{
PENGARUH PENGEMBANGAN KARIR DAN KOMPENSASI FINANSIAL TERHADAP KEPUASAN KERJA SUBDIVISI PLATE MANUFACTURING PT YUASA BATTERY INDONESIA
}

\author{
Sholikhah \\ Fakultas Ekonomi Universitas Negeri Jakarta \\ Email: sholikhahlabs@gmail.com \\ Marisa Andriani \\ Fakultas Ekonomi Universitas Negeri Jakarta \\ Email: marisaandriani96@gmail.com \\ Hania Aminah \\ Fakultas Ekonomi Universitas negeri Jakarta \\ E-mail: haniaaminah@gmail.com
}

\begin{abstract}
ABSTRAK
Tujuan penelitian ini adalah: Untuk mengetahui deskripsi dari pengembangan karir, kompensasi finansial dan kepuasan kerja karyawan subdivisi plate manufacturing PT Yuasa Battery Indonesia, pengaruh pengembangan karir terhadap kepuasan kerja karyawan subdivisi plate manufacturing PT Yuasa Battery Indonesia, pengaruh kompensasi finansial terhadap kepuasan kerja karyawan subdivisi plate manufacturing PT Yuasa Battery Indonesia, model penelitian pengembangan karir dan kompensasi finansial dapat memprediksi kerpuasan kerja karyawan Subdivisi Plate Manufacturing PT Yuasa Battery Indonesia. Penelitian ini dilakukan terhadap 121 orang karyawan subdivisi plate manufacturing PT Yuasa Battery Indonesia. Penelitian ini menggunakan analisis deskriptif dan explanatory. Teknik pengumpulan data menggunakan metode survei yaitu menyebarkan kuisioner yang kemudian diolah dengan progam SPSS 22. Hasil dari regresi menunjukkan bahwa terdapat pengaruh positif dan signifikan antara pengembangan karir terhadap kepuasan kerja, terdapat pengaruh positif dan signifikan antara kompensasi finansial terhadap kepuasan kerja, dan model penelitian pengembangan karir dan kompensasi finansial dapat memprediksikan kepuasan kerja karyawan subdivisi plate manufacturing PT Yuasa Battery Indonesia.
\end{abstract}

Kata Kunci: Pengembangan Karir, Kompensasi Finansial, Kepuasan Kerja 


\section{PENDAHULUAN}

\section{Latar Belakang Masalah}

Keberhasilan suatu organisasi tidak ditentukan oleh besarnya modal yang besar, penggunaan teknologi yang canggih atau bahan yang berkualitas tinggi tetapi sangat tergantung pada peran sumber daya manusia yang mengelolanya. Betapa banyak suatu perusahaan yang mengawali dengan modal besar tetapi pada beberapa kurun waktu tertentu mengalami kebangkrutan, hal in menunjukkan keberadaan sumber daya manusia dalam organisasi sangat menentukan dan memegang peranan penting dalam mengelola dan mengembangkan perusahaan. Secara manajerial harus selalu berusaha mencapai keunggulan kompetitif dibandingkan dengan perusahaan pesaing. Untuk hal tersebut sumber daya manusialah yang mampu mewujudkannya, artinya tuntutan kreativitas, inovasisi harus terus dilakukan agar barang atau jasa yang ditawarkan berdaya saing tinggi dan pada giliranya keahlian dan produktivitaslah yang akan bertahan dipasar.

Kepuasan kerja salah satu hal yang mesti diperhatikan perusahaan dapat tumbuh berkembang karena kepuasan kerja karyawan sangat berpengaruh pada kinerjanya diberbagai level manajemen, bentuk kepuasan kerja biasanya ditunjukkan oleh terpenuhinya harapan karyawan dalam melaksanakan tugasnya. Hal ini dipertegas hasil penelitian yang mengatakan bahwa " kepuasan kerja karyawan ini tidak bisa terlepas dari kenyataan yang menyatakan bahwa kepuasan kerja karyawan dapat tercapai apabila sudah terpenuhinya harapan-harapan dalam melaksanakan pekerjaannya " (Kriswanti, 2017).

Kepuasan kerja merupakan keadaan emosional yang menyenangkan atau tidak menyenangkan dari seorang pekerja dalam memandang pekerjaannya (Kurniawan, 2015). Karyawan yang memiliki kepuasan kerja tinggi akan menunjukan sikap positif terhadap pekerjaannya. Sebaliknya, karyawan yang memiliki kepuasan kerja rendah akan menunjukan sikap negatif terhadap pekerjaannya (Waspodo, Dharmawan, dan Handaru, 2017). Apabila kepuasan kerja bermasalah maka semangat dan gairah kerja akan berkurang sehingga berpengaruh terhadap kinerja karyawan dan pada giliranya akan mempengaruhi produktivitas kerja serta kecenderungan karyawan mengundurkan diri untuk mencari pekerjaan baru. Kondisi ketidakpuasan karyawan harus segera ditangani 
pimpinan agar tidak terjadi kerugian yang lebih besar bagi perusahaan. kepuasan kerja merupakan keadaan emosional yang menyenangkan atau tidak menyenangkan baik positif maupun negartif dari karyawan dalam memandang pekerjaan mereka. Kondisi ketidakpuasan karyawan lama kelamaan

Kepuasan kerja menjadi permasalahan yang sering terjadi di setiap perusahaan, salah satunya perusahaan PT Yuasa Battery Indonesia. Parimita, Pambudi, dan Aminah (2017) menyatakan bahwa tingkat ketidakpuasan kerja dapat dilihat dari tingkat kehadiran karyawan atau kemangkiran karyawan dan keterlambatan masuk karyawan yang diduga karena rutinitas pekerjaan karyawan itu sendiri. Gambar I.1 menggambarkan tingkat absensi karyawan PT Yuasa Battery Indonesia subdivisi plate manufacturing.

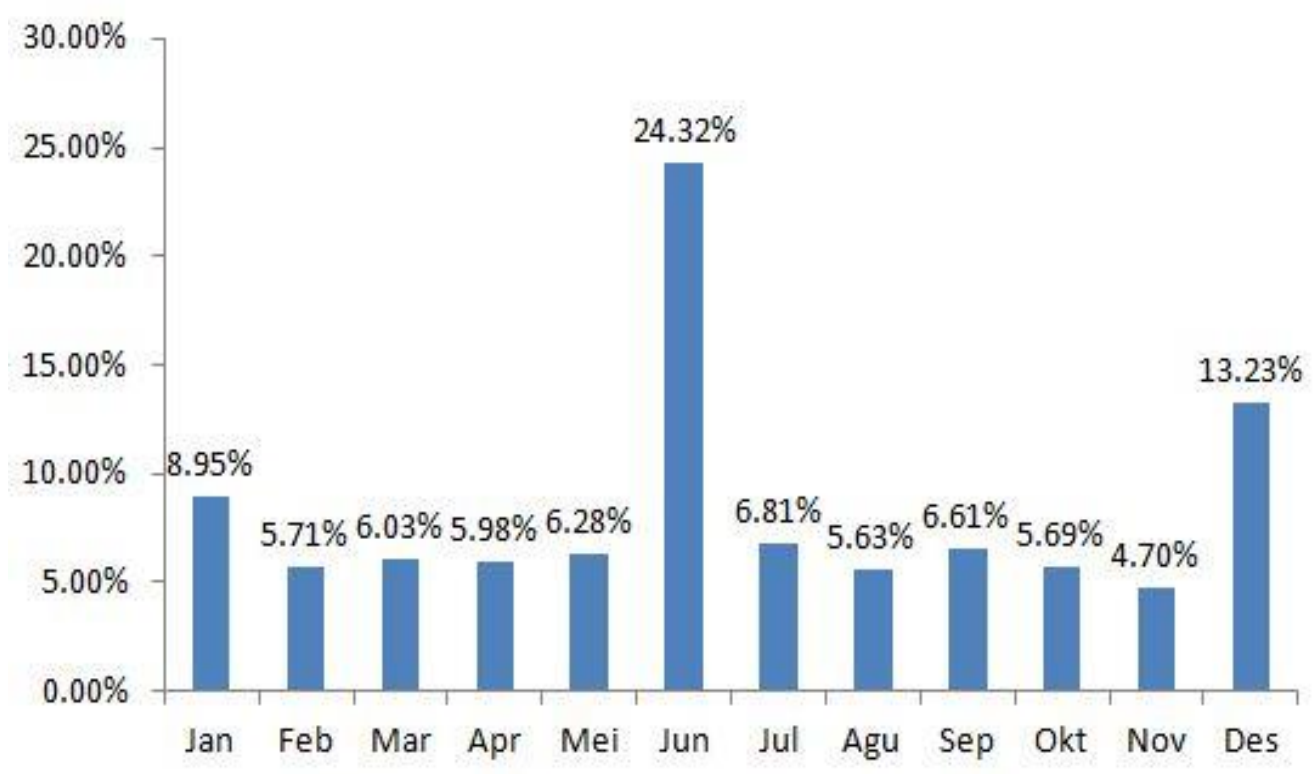

\section{Gambar 1}

Data Absensi Data Absensi Karyawan Bulan Januari - Desember 2017

Sumber : Data dioleh oleh peneliti, 2018

Flippo (2001:281) menyatakan bahwa apabila absensi 0 sampai 2 persen dinyatakan baik, 3 sampai 10 persen dinyatakan tinggi, dan diatas 10 persen dinyatakan tidak wajar. Gambar I.1 memberikan gambaran bahwa ketidak hadiran pada PT Yuasa Bateery Indonesia khususnya subdevisi plate manufacturing tinggi. Bila dicermati secara menyeluruh maka angka ketidakhadiran pada bulan juni sangatlah tinggi mencapai 24,32 \% ternyata hal terjadi karena kebijakan perusahaan memberikan cuti sebagain karyawan dan banyaknya hari libur pada 
bulan hari raya idul fitri ditunjang karyawan yang mangkir dengan alasana pulang kampung. Lebih lanjut bisa dilihat setiap bulan karyawan banyak yang tidak hadir rata-rata per bulan lebih 5\% bahkan dibulan desember mencapai $13,23 \%$ ini menunjukkan ketidak hadiran bisa dijadikan salah satu indikasi kepuasan kerja yang rendah.

Setiap orang yang bergabung dalam suatu organisasi atau perusahaan pasti berharap dapat mencapai level manajemn yang lebih tinggi dari satu periode keperiode berikutnya atau istilah populernya dapat mengembangkan karir sesuai dengan keahliannya. Ketidakjelasan karir dalam perusahaan dapat menumbuhkan apatisme karyawan dan dapat berpengaruh terhadap hasil kerja Pengembangan karir merupakan faktor yang harus diperhatikan dan dikelola dengan baik karena akan meningkatkan kemampuan dan keahlian karyawan sehingga dapat mengetahui fungsi, peranan, dan tanggung jawab di lingkungan kerjanya. Pengembangan karir diharapkan dapat menciptakan kepuasan kerja yang lebih tinggi karena tersedianya peluang untuk dapat meningkatkan keahlian, dan karir (Sari, 2015). Hasil penelitian tersebut menunjukkan bahwa pengembangan karir mempengaruhi kepuasan kerja secara signifikan.

Kompensasi finansial menjadi pertimbangan utama seseorang bersedia bekerja dalam perusahaan dan bertahan tidaknya disuatu perusahaan, fakta menunjukkan kecenderungan seseorang bekerja untuk meraih kehidupan yang lebih baik atau paling tidak dapat bertahan hidup. Besar kecilnya kompensasi yang diterima sangat mempengaruhi kepuasan kerja karyawan terbesar kedua yang mempengaruhi rendahnya kepuasan kerja karyawan subdivisi plate manufacturing PT Yuasa Battery Indonesia. Pemberian balas jasa secara finansial setidaknya dapat menjamin kehidupan secara layak bagi karyawannya, Ketidak tepatan dalam memberikan kompensasi dapat menimbulkan konflik bagi perusahaan karena kemungkinan terjadi gejolak sosial jelas akan merugikan perusahaan. Oleh karena itu pemberian kompensasi harus secara jelas dikomonikasikan secara jelas dan terbuka dari awal penerimaan. Kesalahan menetapkan kompensasi finansial yang didapat karyawan akan mengakibatkan kerugian perusahaan karena karyawan yang merasa tidak puas akan balas jasa 
yang didapat. Kompensasi finansial yang diberikan kepada pegawai dengan adil dan layak berpengaruh terhadap kepuasan kerja karyawannya (Kurniawan, 2015).Hasil penelitian tersebut menunjukkan bahwa kompensasi finansial mempengaruhi kepuasan kerja secara signifikan.

\section{TELAAH PUSTAKA}

\section{Kepuasan Kerja}

Badeni (2013:43) menjelaskan kepuasan kerja sesungguhnya merupakan sikap seseorang terhadap pekerjaannya yang dapat berupa sikap positif atau negatif, puas atau tidak puas. Senada dengan Badeni, Robbins dan judge (2009:113) menyatakan “Job satisfaction is positive feeling about one's job resulting from an evaluation of its characteristics". Dapat diartikan bahwa kepuasan kerja adalah perasaan positif seseorang terhadap pekerjaannnya yang merupakan hasil dari evaluasi karakteristik-karakteristik.

Kreitner dan Kinicki (2008:202) menyatakan "Job Satisfaction is an effective or emotional response toward various facet of one's job". Dalam arti luas kepuasan kerja adalah efektifitas atau respon emosional terhadap berbagai aspek pekerjannya. Sedangkan menurut (Rivai dan Mulyadi, 2012) "Kepuasan kerja adalah penilaian pekerja mengenai seberapa jauh pekerjaannya memuaskan kebutuhannya".

Dari beberapa definisi kepuasan kerja tersebut dapat disimpulkan,kepuasan kerja merupakan cara pandang, penilaian, dan respon emosional seseorang baik positif maupun negative terhadap aspek pekerjaannya. Sikap yang menyenangkan atau tidak menyenangkan yang tercermin dalam disiplin, moral dan prestasi kerja.. Kepuasan kerja berkaitan dengan kondisi akhir yang timbul karena tercapainya tujuan tertentu dan seberapa jauh pemenuhan kebutuhan karyawan tersebut.

Teori tentang kepuasan kerja dalam penelitian ini menggunakan penerapan teori dua faktor (Two Factor Theory) yang ditunjang oleh Herzberg, teori ini menghubungkan kondisi di sekitar pekerjaan yang dinamakan Hygiene factors seperti kondisi kerja, pengupahan, keamanan, kualitas pengawasan, hubungan dengan orang lain, karakteristik pekerjaan, peluang untuk berkembang. 
Dan juga satisfiers yang meliputi kesempatan untuk berprestasi, penghargaan dan promosi. Bila faktor higienis sudah mencukupi maka akan memenuhi kebutuhan dasar karyawan lebih banyak. Pemenuhan atas kebutuhan itu mencegah karyawan dari ketidakpuasan, sehingga karyawan menjadi termotivasi untuk meraih kebutuhan yang lebih tinggi lagi (Mursi, 1997) dalam (Muayyad et al., 2016).

Teori Dua faktor ini dikembangkan oleh Frederick Irving Herzberg (19232000), seorang psikolog asal Amerika Serikat. Penggunaan teori kepuasan kerja tersebut diatas sudah disesuaikan dengan tujuan pemakaiannya. Dalam penelitian ini peniliti menggunakan teori dua faktor tersebut untuk menjelaskan hubungan kompensasi dengan kepuasan kerja. Alasan teori dua faktor ini karena teori tersebut lebih tepat untuk mengetahui tingkat kepuasan kerja dari aspek-aspek yang sudah ditentukan seperti pekerjaan itu sendiri, imbalan atau gaji, kesempatan promosi, pengawasan, dan rekan kerja.

Implikasi teori Dua-Faktor menyiratkan bahwa manager harus fokus untuk menjamin kecukupan faktor hygiene guna menghindari ketidakpuasan meningkatkan motivasi karyawan untuk bekerja lebih baik.

\section{Pengembangan Karir}

Noe (2008:415) menyatakan "Career development is the process by which employees progress through a series of stager, each characterized by a different set of development tasks, activities, and relationships". Secara umum pengembangan karir dapat diartikan proses di mana karyawan mengalami kemajuan melalui serangkaian sikap yang masing-masing dicirikan oleh serangkaian tugas, hubungan, dan aktivitas yang berbeda. Lalu dalam bukunya Robbins (2001) mendefinisikan pengembangan karir adalah suatu yang menunjukkan adanya peningkatan-peningkatan status seseorang dalam suatu organisasi dalam jalur karir yang telah ditetapkan dalam organisasi yang bersangkutan.

Rivai dan Sagala (2009:274) dalam bukunya mengemukakan pengembangan karir adalah proses peningkatan kemampuan kerja individu yang dicapai dalam rangka mencapai karir yang diinginkan.

Berdasarkan definisi tersebut dapat disentasikan, pengembangan karir 
adalah proses dari upaya untuk meningkatkan kemampuan dan pengembangan karyawan agar lebih baik. Proses peningkatan tersebut dapat melalui sikap yang dicirikan oleh serangkaian tugas, hubungan dan aktivitas yang berbeda.

Simamora (2006:412) mengutarakan bahwa terdapat dua dimensi pengembangan karir, yaitu:

1). Perencanaan karir (career planning)

\section{2). Manajemen karir (career management)}

Karir setiap karyawan perlu direncanakan melalui proses identifikasi dari tujuan yang ingin dicapai dan dilakukan secara sadar atas peluang dan menyusun program kerja sesuai melalui pemahaman diri, sikap terhadap karir dan identifikasi tujuan karir.

Manajemen karir dapat terwujud bila perusahaan diprogram secara jelas dan terbuka serta diorganisir agar sesuai antara keinginan karyawan untuk mengembangkan karir dan kebutuhan perusahaan. Hal ini dipertegas Sulistiyani dan Rosidah (2003 : 283) Pengembangan karir merupakan proses dimana pihak perusahaan memilih, menilai, menugaskan, serta mengembangkan karyawannya dengan menyediakan suatu kumpulan individu yang memiliki keunggulan tertentu agar dapat memenuhi kebutuhan di masa yang akan datang.

Sedangkan menurut Siagian (2008:215) dimensi pengembangan karir terbagi menjadi tujuh hal, yaitu:

1). Prestasi kerja

2). Pengenalan oleh pihak lain

3). Kesetiaan pada organisasi

4). Pemanfaatan Mentors dan Sponsor

5). Dukungan para bawahan

6). Pemanfaatan kesempatan untuk bertumbuh

7). Berhenti atas permintaan dan kemauan sendiri

\section{Kompensasi Finansial}

Wilson (2012:255) mengemukakan kompensasi finansial ialah bentuk kompensasi yang dibayarkan kepada karyawan dalam bentuk uang atau jasa yang mereka sumbangkan pada pekerjaannya. Menurut Saydam (2000:235) dalam 
bukunya kompensasi finansial yaitu berupa gaji atau upah, bonus, dan tunjangan menjadi salah satu kunci penting bagi roda kehidupan suatu perusahaan.

Boone dan Kurtz (2009:327) menjelaskan Kompensasi finansial adalah salah satu penghargaan atau ganjaran dalam bentuk uang yang mencakup upah (wage) dan gaji (salary) di tambah dengan tunjangan-tunjangan (benefit). Menurut Rivai (2011:741) dalam bukunya kompensasi finansial terdiri dari kompensasi finansial langsung dan tidak langsung. Kompensasi finansial langsung terdiri dari upah, gaji, pembayaran prestasi, insentif, bonus, dan pembayaran tertangguh yang meliputi tabungan hari tua, dan saham komulatif yang sesuai dengan beban pekerjaan dan prestasi karyawan. Kompensasi finansial tidak langsung meliputi liburan, berbagai macam asuransi, dan pemberian tunjangan hari raya.

Berdasarkan pendapat definisi kompensasi finansi menurut para ahli diatas, kompensasi finansial merupakan sesuatu yang diterima karyawan sebagai balas jasa, penghargaan, atau ganjaran kepada karyawannya atas jasa yang mereka sumbangankan ke perusahaan. Balas jasa yang diberikan perusahaan bisa dalam bentuk kompensasi langsung seperti gaji, upah, insentif, bonus dan kompensasi tidak langsung seperti tunjangan, asuransi, dan fasilitas lainnya.

\section{TEORI KOMPENSASI}

\section{Teori Upah Substansi}

David Ricardo (1772 - 1823) seorang ahli ekonomi klasik dari Inggris menciptakan teori upah substansi dengan memanfaatkan teori hukum penawaran dan permintaan Adam Smith. semakin tinggi tingkat kelahiran dan selanjutnya semakin meningkat juga pertumbuhan angkatan kerja yang mencari lapangan pekerjaan dan bersedia kerja walaupun upahnya ditekan serendah mungkin oleh pengusaha sampai ke tingkat substansi.

\section{Teori Dana Tetap untuk Upah}

Seorang ahli ekonomi Inggris yang bernama John Stuard Mill (1803-1873) berpendapat bahwa pada setiap negara terdapat dana yang terbatas untuk upah. Dana untuk upah merupakan bagian dari dana masyarakat yang dihimpun dari tabungan.

\section{Teori Investasi Sumber Daya Manusia}

Teori ini mendasarkan asumsinya bahwa setiap tambahan investasi terhadap sumber daya manusianya dalam pendidikan, pelatihan pengalaman kerja, gizi dan kesehatan akan 
menambah kemampuan berproduksi dari orang yang bersangkutan. Sedangkan upah merupakan imbalan atas nilai produk yang dihasilkan oleh seseorang pekerja.

Berdasarkan beberapa teori tersebut penetapan upah atau gaji pada perusahaan mengkombinasikan antara teori dana tetap dengan investasi sumber daya manusia, hal ini pihak perusahaan mempertimbangkan disamping menetapkan tingkat gaji karyawan tetapi juga memberikan insentif berupa peningkatan kualitas sumber daya manusia bagi karyawan yang potensial

\section{Model Penelitian}

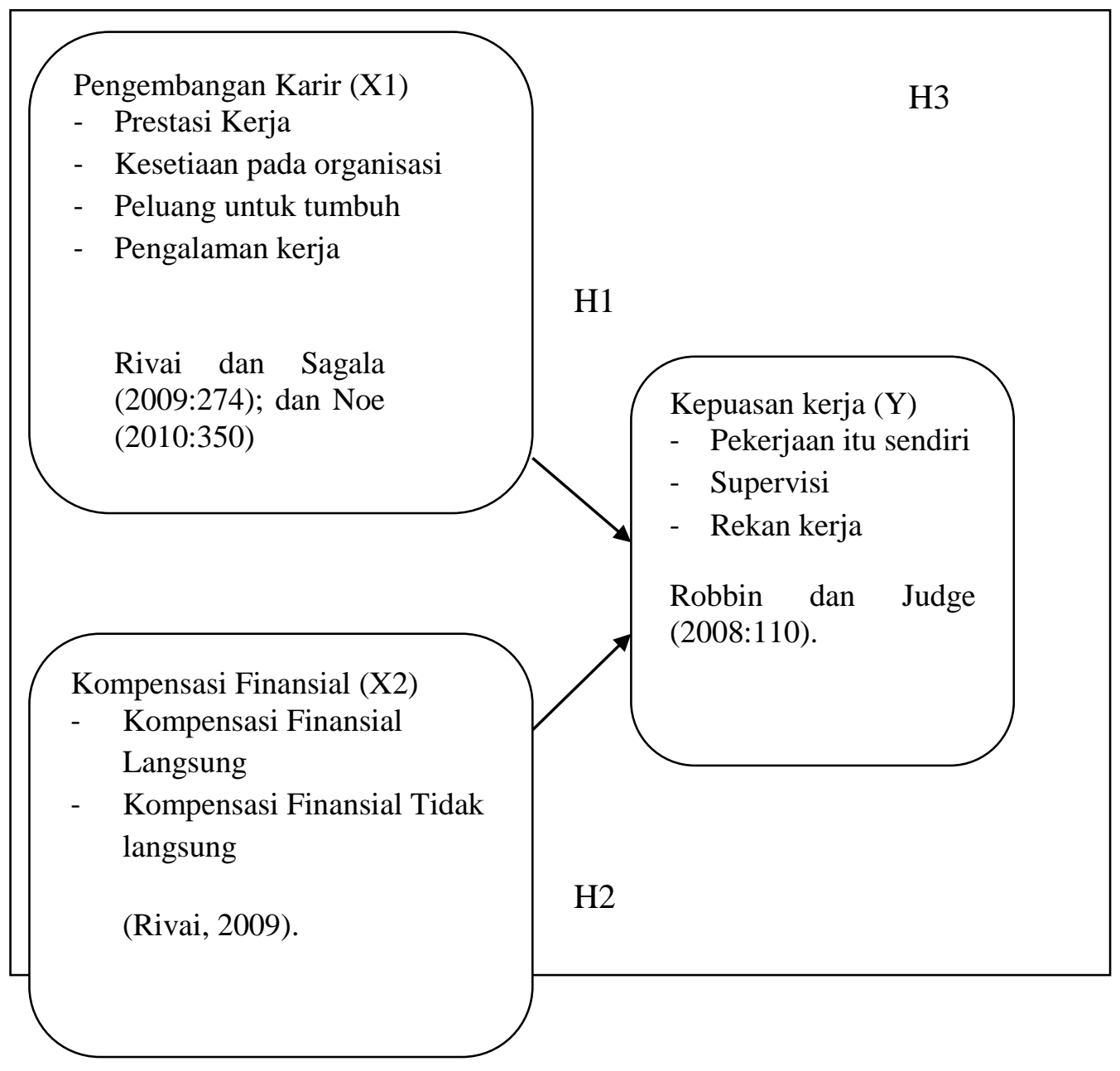

Gambar 2. Kerangka Pemikiran 
Berdasarkan kajian teori dan model penelitian di atas maka hipotesis pada penelitian ini adalah:

\section{Hipotesis 1:}

$\mathrm{H}_{0}$ : Pengembangan karir tidak berpengaruh terhadap kepuasan kerja.

$\mathrm{H}_{\mathrm{a}}$ : Pengembangan karir berpengaruh terhadap kepuasan kerja.

\section{Hipotesis 2:}

$\mathrm{H}_{0}$ : Kompensasi finansial tidak berpengaruh terhadap kepuasan kerja.

$\mathrm{H}_{\mathrm{a}} \quad$ : Kompensasi finansial berpengaruh terhadap kepuasan kerja.

\section{Hipotesis 3:}

$\mathrm{H}_{0}$ : Pengembangan karir dan kompensasi finansial tidak dapat memprediksi model terhadap kepuasan kerja.

$\mathrm{H}_{\mathrm{a}} \quad$ : Pengembangan karir dan kompensasi finansial dapat memprediksi model terhadap kepuasan kerja.

\section{METODOLOGI PENELITIAN}

Metode penelitian deskriptif dan explanatory. Pendekatan yang digunakan dalam penelitian ini adalah kualitatif dan kuantitatif. Hal dimaksudkan untuk mendeskripsikan tentang fakta yang ada dalam obyek penelitian melalui wawancara ataupun hasil pengolahan data sekunder. Sementara analisa kuantitatif dilakukan untuk mencari seberapa besar model yang ditawarkan variabel bebas dapat menjelaskan atas variabel terikat sebagai hasil analisa data primer. PData yang digunakan dalam penelitian ini berasal dari data primer. Teknik pengambilan sampel adalah probability sampling. Populasi adalah karyawan subdivisi plate manufacturing PT Yuasa Battery Indonesia yang berjumlah 173 orang. Berdasarkan perhitungan metode Slovin maka jumlah sampel sebanyak 121 karyawan subdivisi plate manufacturing PT Yuasa Battery Indonesia.

\section{HASIL DAN PEMBAHASAN}

\section{Uji Instrumen}

\section{Uji Validitas}

Uji validitas menunjukkan sejauh mana suatu alat pengukur dapat mengukur sesuatu yang ingin diukur oleh peneliti. Alat pengukur yang digunakan korelasi product moment., kriterianya adalah jika nilai $\mathrm{r}$ hitung $>\mathrm{r}$ tabel maka 
instrumen dinyatakan valid dan sebaliknya.

Hasil uji validitas dapat dilihat pada Tabel 2. berikut ini:

\begin{tabular}{lccc}
\multicolumn{4}{c}{ Tabel 1. Hasil Uji Validitas } \\
\hline \multicolumn{1}{c}{ Variabel } & $\begin{array}{c}\text { Pernyataa } \\
\text { n }\end{array}$ & $\begin{array}{c}\text { Item } \\
\text { Valid }\end{array}$ & Item Tidak Valid \\
\hline $\begin{array}{l}\text { Kepuasan Kerja } \\
\text { Pengembangan }\end{array}$ & 9 & 12 & 0 \\
$\begin{array}{l}\text { Karir } \\
\text { Kompensasi }\end{array}$ & 9 & 9 & 0 \\
Finansial & 9 & 0 \\
\hline $\begin{array}{l}\text { mber : Data diolah oleh peneliti (2019) } \\
\text { (2) }\end{array}$ & &
\end{tabular}

Hasil pengolahan data menunjukkan semua questionare dari tiga variabel yaitu variabel kepuasan kerja, pengembangan karir, dan kompensasi finansial adalah valid dengan membandingkan nilai $\mathrm{r}_{\text {hitung }}<\mathrm{r}_{\text {tabel }}(0.361)$.

\section{Uji Reliabilitas}

Uji reliabilitas digunakan untuk mengetahui derajat ketepatan, ketelitian, atau keakuratan yang ditunjukkan oleh instrumen pengukuran. Kriteria pengujian reliabilitas adalah jika nilai cronbach's alpha >0.6, maka instrumen reliabel. Sebaliknya jika nilai cronbach's alpha $<0.6$ maka instrumen tidak reliabel.Hasil uji reliabilitas masing-masing variabel dapat dilihat pada Tabel 2. berikut :

Tabel 2. Hasil Uji Reliabilitas

\begin{tabular}{lcl}
\hline \multicolumn{1}{c}{ Variabel } & Cronbach's Alpha & Keterangan \\
\hline Kepuasan Kerja $(\mathrm{Y})$ & 0.826 & Reliabel \\
Pengembangan Karir $\left(\mathrm{X}_{1}\right)$ & 0.803 & Reliabel \\
Kompensasi Finansial $\left(\mathrm{X}_{2}\right)$ & 0.828 & Reliabel \\
\hline
\end{tabular}

Sumber : Data diolah oleh peneliti (2019)

Pada Tabel 2. terlihat nilai Cronbach's Alpha > 0.6 pada variabel kepuasan kerja sebesar 0.826, pengembangan karir sebesar 0.803, kompensasi finansial sebesar 0.828. Maka instrumen tersebut dinyatakan reliabel.

\section{Hasil Analisis Deskriptif}

Berdasarkan kuesioner yang disebarkan kepada responden bahwa variabel kepuasan kerja memperoleh skor tidak setuju (ts) sebesar $14.49 \%$, sehingga jika di total keduanya sebesar $62.35 \%$. Berada dalam interval skor $51-75 \%$ dengan keterangan rendah. Dapat diartikan bahwa kepuasan kerja yang dirasakan oleh karyawan tergolong rendah. Kontribusi terbesar yang menyebabkan kepuasan 
kerja karyawan masih rendah terdapat pada dimensi supervisi, dimana sebanyak 80.17\% Karyawan merasa atasan kurang memberikan karyawan kesempatan untuk berpartisipasi dalam membuat keputusan pekerjaan.

Pada variabel pengembangan karir memperoleh skor tidak setuju (ts) skor tidak setuju (ts) sebesar $48.48 \%$ dan skor sangat tidak setuju $15.01 \%$ sehingga jika di total keduanya mendapatkan hasil sebesar $63.49 \%$. Berada dalam interval skor 51\%-75\% dengan keterangan kurang baik. Dapat diartikan bahwa pengembangan karir pada karyawan subdivisi plate manufacturing PT Yuasa Battery Indonesia masih kurang baik. Kontribusi terbesar yang menyebabkan pengembangan karir karyawan masih kurang baik terdapat pada dimensi peluang untuk tumbuh, dimana sebanyak $85.12 \%$ karyawan merasa kurang diberikan kesempatan oleh perusahaan untuk mengikuti pelatihan.

Pada variabel kompensasi finansial memperoleh skor tidak setuju (ts) sebesar $46.38 \%$ dan skor sangat tidak setuju (sts) $14.59 \%$ sehingga jika di total keduanya mendapatkan hasil sebesar $60.97 \%$. Berada dalam interval skor 51\%$75 \%$ dengan keterangan kurang layak... Kontribusi terbesar yang menyebabkan kompensasi finansial karyawan masih kurang layak terdapat pada dimensi kompensasi finansial langsung, dimana sebanyak 71.90\% karyawan merasa belum puas dengan gaji yang diterima setiap bulannya.

\section{Uji Asumsi Klasik}

\section{Hasil Uji Normalitas}

Uji normalitas digunakan untuk mengetahui apakah data berdistribusi normal atau tidak. Uji ini menggunakan uji Kolmogrov-Smirnov dan dinyatakan berdistribusi normal jika signifikansi lebih besar dari 0.05.Hasil uji normalitas dapat dilihat pada Tabel 3. berikut:

Tabel 3. Hasil Uji Normalitas

One-Sample Kolmogorov-Smirnov Test

\begin{tabular}{ll}
\multicolumn{2}{c}{ One-Sample Kolmogorov-Smirnov Test } \\
\hline & Unstandardized Residual \\
\hline $\mathrm{N}$ & \\
121 & \\
Normal Parameters $^{a, b}$ & Mean \\
& .0000000 \\
& Std. Deviation \\
& 3.04795272
\end{tabular}




\begin{tabular}{llr} 
Most Extreme Differences & $\begin{array}{l}\text { Absolute } \\
\text { Positive }\end{array}$ & .061 \\
& Negative & .041 \\
& .061 & - \\
Test Statistic & & .061 \\
Asymp. Sig. (2-tailed) & & $.200^{\mathrm{c}, \mathrm{d}}$ \\
\hline
\end{tabular}

Sumber : Data diolah oleh peneliti (2019)

Berdasarkan Tabel 3. Dapat terlihat bahwa nilai Asymp. Sig melebihi dari $\alpha=0,05$ yaitu sebesar 0,20 , ini menyatakan bahwa data berdistribusi normal. Terdistribusi dengan normal memiliki arti bahwa sampel dapat mewakili populasi sehingga penelitian dapat digeneralisasikan pada populasi.

\section{Hasil Uji Linearitas}

Uji linearitas dilakukan sebelum dilakukan analisis regresi untuk mengetahui apakah variabel bebas mempunyai hubungan linier atau tidak secara signfikan terhadap variabel terikat. Pengujian ini dilakukan menggunakan test for linearity. Pengujian Test for Linearity dengan pada taraf signifikansi 0,05. Dua variabel dikatakan mempunyai hubungan yang linear bila signifikansi (Linearity) kurang dari 0,05 .

Tabel 4. Hasil Uji Linearitas ANOVA Table

\begin{tabular}{|c|c|c|c|c|c|c|c|}
\hline & & & $\begin{array}{l}\text { Sum of } \\
\text { Squares }\end{array}$ & df & $\begin{array}{l}\text { Mean } \\
\text { Square }\end{array}$ & $\mathbf{F}$ & Sig. \\
\hline \multirow{6}{*}{$\begin{array}{l}\text { Kepuasan Kerja } \\
* \\
\text { Pengembangan } \\
\text { Karir }\end{array}$} & Between & (Combined) & 4347.154 & 17 & 255.715 & 26.856 & .000 \\
\hline & Groups & Linearity & 3795.982 & 1 & 3795.982 & 398.668 & .000 \\
\hline & & Deviation & & & & & \\
\hline & & $\begin{array}{l}\text { from } \\
\text { Linearity }\end{array}$ & 551.172 & 16 & 34.448 & 3.618 & .000 \\
\hline & Within $G$ & roups & 980.730 & 103 & 9.522 & & \\
\hline & Total & & 5327.884 & 120 & & & \\
\hline
\end{tabular}

Sumber: Data diolah oleh peneliti (2019)

Berdasarkan hasil uji linearitas antara variabel kepuasan kerja dengan variabel pengembangan karir pada Tabel 4. terlihat bahwa nilai signifikansi sebesar 0,00 atau kurang dari 0.05, dapat disimpulkan bahwa terdapat hubungan 
linear antara variabel pengembangan karir $\left(\mathrm{X}_{1}\right)$ dengan variabel kepuasan kerja $(\mathrm{Y})$.

Tabel 5. Hasil Uji Linearitas

ANOVA Table

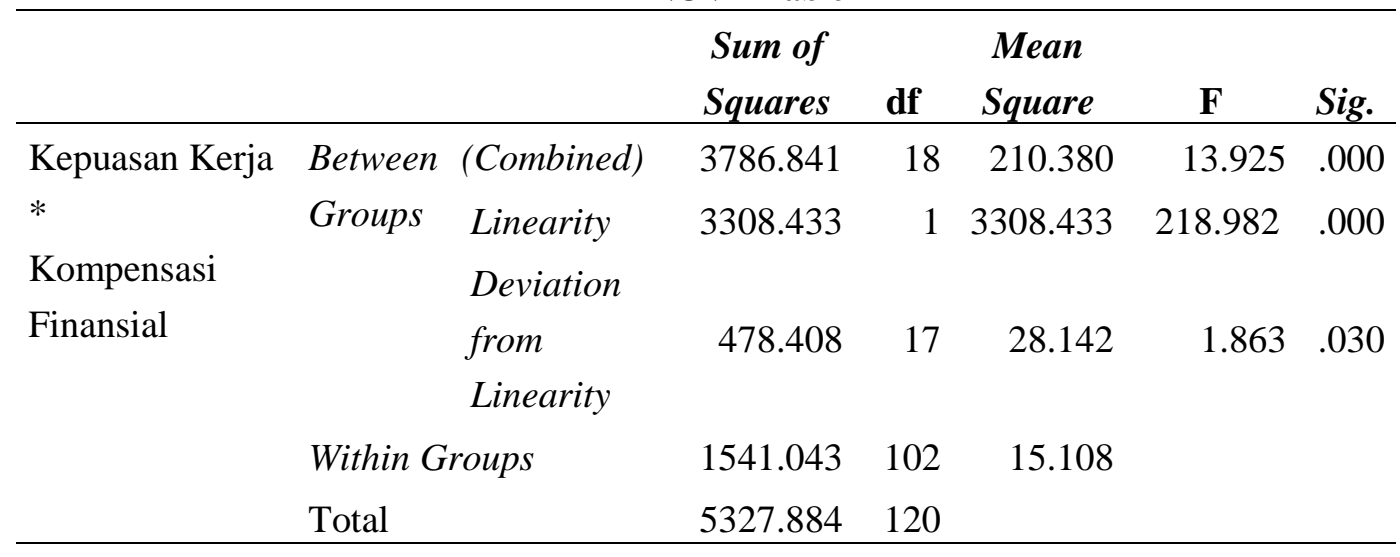

Sumber: Data diolah oleh peneliti (2019)

Berdasarkan uji linearitas antara variabel kepuasan kerja dengan kompensasi finansial pada tabel 5. terlihat bahwa nilai signifikansi sebesar 0.00 atau kurang dari 0.05 , dapat disimpulkan bahwa terdapat hubungan linear antara variabel kompensasi finansial $\left(\mathrm{X}_{2}\right)$ dengan variabel kepuasan kerja $(\mathrm{Y})$.

\section{Hasil Uji Multikolinearitas}

Uji multikolinearitas bertujuan untuk menguji apakah model regresi ditemukan adanya korelasi antar variabel bebas (independen). Syarat penentuan ada atau tidaknya multikolinearitas yaitu jika nilai tolerance value $<0,10$ dan VIF $>5$ terjadi multikolinearitas dan jika nilai tolerance value $>0,10$ dan VIF $<5$ tidak terjadi multikolinearitas. Hasil uji multikolinearitas dapat dilihat pada Tabel 6. berikut ini

Tabel 6. Hasil Uji Multikolinearitas

\section{Coefficient $\mathbf{a}^{\mathrm{a}}$}

$\mathbf{S}$

\begin{tabular}{llll}
\hline Model & \multicolumn{2}{c}{ Collinearity Statistics } \\
& & Tolerance & VIF \\
\hline 1 & (Constant) & & \\
& Pengembangan_Karir & .516 & 1.936 \\
& Kompensasi FInansial & .516 & 1.936 \\
\hline
\end{tabular}

Sumber: Data diolah oleh peneliti (2019) 
Dilihat dari tabel 6 dapat terlihat bahwa nilai tolerance pengembangan karir dan kompensasi finansial sebesar 0,516 yang berarti > 0,10. Selain itu nilai VIF pengembangan karir dan kompensasi finansial sebesar 1,936 yang berarti $<5$. Dapat disimpulkan dari hasil tersebut bahwa tidak terjadi masalah multikolinieritas dalam data penelitian. Sehingga pada model regresi ditemukan korelasi antar variabel bebas yaitu pengembangan karir dan kompensasi finansial.

\section{Hasil Uji Heteroskedastisitas}

Uji heterokedastisitas bertujuan untuk menguji apakah dalam sebuah model regresi terjadi ketidaksamaan varian dari suatu residual satu pengamatan ke pengamatan lainnya. Pada penelitian ini menggunakan analisis uji spearman's rho dengan menkorelasikan nilai residual dengan masing-masing variabel penelitian, dengan syarat jika nilai signifikan korelasinya $<0,05$ maka terjadi heterokedastisitas dan jika nilai signifikan korelasinya $>0,05$ maka tidak terjadi heterokedastisitas.

Tabel 7. Hasil Uji Heteroskedastisitas

Correlations

\begin{tabular}{|c|c|c|c|c|c|}
\hline & & & $\begin{array}{c}\text { Pengembangan } \\
\text { karir }\end{array}$ & $\begin{array}{c}\text { Kompensasi } \\
\text { Finansial }\end{array}$ & ABS_RES \\
\hline \multirow[t]{9}{*}{$\begin{array}{l}\text { Spearman's } \\
\text { rho }\end{array}$} & $\begin{array}{l}\text { Pengembangan } \\
\text { karir }\end{array}$ & $\begin{array}{l}\text { Correlation } \\
\text { Coefficient }\end{array}$ & 1.000 & $.626^{* *}$ & .121 \\
\hline & & Sig. (2-tailed) & & .000 & 188 \\
\hline & & $\mathrm{N}$ & 121 & 121 & 121 \\
\hline & $\begin{array}{l}\text { Kompensasi } \\
\text { Finansial }\end{array}$ & $\begin{array}{l}\text { Correlation } \\
\text { Coefficient }\end{array}$ & $.626^{* *}$ & 1.000 & .118 \\
\hline & & Sig. (2-tailed) & .000 & & .198 \\
\hline & & $\mathrm{N}$ & 121 & 121 & 121 \\
\hline & ABS_RES & $\begin{array}{l}\text { Correlation } \\
\text { Coefficient }\end{array}$ & .121 & .118 & 1.000 \\
\hline & & Sig. (2-tailed) & .188 & .198 & \\
\hline & & $\mathrm{N}$ & 121 & 121 & 121 \\
\hline
\end{tabular}

Sumber: Data diolah oleh peneliti (2019)

Dari Tabel 7, menunjukan hasil uji heterokedastisitas dengan mengkorelasi nilai residual dengan masing-masing variabel penelitian. Dapat terlihat bahwa nilai signifikansi variabel Pengembangan karir $\left(\mathrm{X}_{1}\right)$ sebesar $0.188>0.05$ dan variabel kompensasi finansial $\left(\mathrm{X}_{2}\right)$ sebesar $0.198>0.05$, dapat disimpulkan bahwa tidak terjadi masalah heterokedastisitas karena nilai signifikansinya $>0.05$. 
sehingga adanya varians yang berbeda dari residual suatu pengamatan ke pengamatan lain dalam pengembangan karir dan kompensasi finansial..

\section{Persamaan Regresi Linear Berganda}

Analisis yang digunakan dalam penelitian ini adalah regresi linier berganda yang bertujuan untuk mengetahui hubungan secara linier antara dua atau lebih variabel bebas dengan variabel terikat, dalam penelitian ini berarti $\mathrm{X}_{1}$ dan $\mathrm{X}_{2}$ dengan Y. Berikut adalah hasil perhitungan uji regresi berganda:

Tabel 8. Hasil Pengujian Regresi Linear Berganda

Coefficients $^{a}$

\begin{tabular}{|c|c|c|c|c|c|c|}
\hline & & \multicolumn{2}{|c|}{$\begin{array}{c}\text { Unstandardized } \\
\text { Coefficients } \\
\end{array}$} & \multirow{2}{*}{$\begin{array}{c}\text { Standardized } \\
\text { Coefficients }\end{array}$} & \multirow[b]{2}{*}{$\mathbf{t}$} & \multirow[b]{2}{*}{ Sig. } \\
\hline & & $\boldsymbol{B}$ & Std. Error & & & \\
\hline \multirow[t]{3}{*}{1} & (Constant) & .958 & 1.271 & & .754 & .452 \\
\hline & $\begin{array}{l}\text { Pengembangan } \\
\text { karir }\end{array}$ & .783 & .080 & .573 & 9.785 & .000 \\
\hline & $\begin{array}{l}\text { Kompensasi } \\
\text { Finansial }\end{array}$ & .492 & .074 & .389 & 6.645 & .000 \\
\hline
\end{tabular}

Dari tabel 8. dapat diperoleh persamaan regresi berganda sebagai berikut:

$$
\begin{aligned}
Y & =a+b_{1} X_{1}+b_{2} X_{2} \\
& =0.958+0,783 X_{1}+0,492 X_{2}
\end{aligned}
$$

Berdasarkan persamaan di atas dapat disimpulkan persamaan regresi sebagai berikut:

1. Koefisien regresi Pengembangan karir $\left(X_{1}\right)$ sebesar 0,783 , menyatakan bahwa apabila pengembangan karir $\left(\mathrm{X}_{1}\right)$ mengalami peningkatan sebesar 1 poin, maka kepuasan kerja (Y) akan meningkat sebesar 0,783 pada konstanta sebesar 0.958 dengan asumsi nilai koefisien $\mathrm{X}_{2}$ tetap. Koefisien $\mathrm{X}_{1}$ bernilai positif artinya terdapat pengaruh antara pengembangan karir dengan kepuasan kerja. Hal ini menjelaskan bahwa semakin meningkat pengembangan karir, maka semakin meningkat pula kepuasan kerjanya. Hal tersebut senada dengan teori yang dikemukakan Sari (2015) yang menyatakan pengembangan karir dapat 
menciptakan kepuasan kerja yang lebih tinggi karena tersedianya peluang untuk dapat meningkatkan keahlian, dan karir. Dengan pengembangan karir diharapkan dapat mencapai tingkat kepuasan kerja yang lebih tinggi dan mendapat kejelasan akan jenjang karir yang mereka capai (Parimita, Wahda, Handaru, 2015).

2. Koefisien regresi kompensasi finansial $\left(X_{2}\right)$ sebesar 0,492 yang berarti apabila kompensasi finansial $\left(\mathrm{X}_{2}\right)$ mengalami peningkatan sebesar 1 poin maka kepuasan kerja (Y) akan meningkat sebesar 0,492 pada konstanta 0.958 dengan asumsi nilai koefisien $\mathrm{X}_{1}$ tetap. Koefisien $\mathrm{X}_{2}$ bernilai positif artinya terdapat pengaruh antara kompensasi finansial dengan kepuasan kerja Hal ini menjelaskan bahwa semakin meningkat kompensasi finansial maka semakin meningkat pula kepuasan kerjanya. Hal tersebut setara dengan teori yang dikemukakan oleh Kurniawan (2015) yang menyatakan "Kompensasi finansial yang diberikan kepada pegawai dengan adil dan layak berpengaruh terhadap kepuasan kerja karyawannya". Lalu, Syah (2013) menyatakan apabila kompensasi finansial yang berupa gaji, bonus, dan tunjangan yang diterima ternyata tidak sesuai dengan harapan, maka hal ini akan menimbulkan ketidakpuasan dalam diri karyawan.

\section{Hasil Uji t}

Uji signifikansi parsial dilakukan untuk mengetahui apakah variabel independent $(\mathrm{X})$ mempunyai pengaruh yang nyata atau signifikan dengan variabel dependent (Y), pengujian dilakukan dengan menggunakan uji t pada taraf signifikansi 0,05. Dasar dari pengambilan keputusan adalah membandingkan $t_{\text {hitung }}$ dengan $t_{\text {tabel }}$ sebagai berikut:

1) H0 diterima jika $t_{\text {hitung }}<t_{\text {tabel }}$ atau nilai signifikansi lebih besar dari 0.05 .

2) $\mathrm{H} 0$ ditolak jika thitung $>\mathrm{t}_{\text {tabel }}$ atau nilai signifikansi lebih kecil dari 0.05 . 
Coefficients $^{\mathbf{a}}$

\begin{tabular}{lllllll}
\hline & \multicolumn{7}{c}{$\begin{array}{c}\text { Unstandardized } \\
\text { Coefficients }\end{array}$} & $\begin{array}{c}\text { Standardized } \\
\text { Coefficients }\end{array}$ & & \\
\hline Model & & B & Std. Error & Beta & t & Sig. \\
\hline 1 & $\begin{array}{l}\text { (Constant) } \\
\text { Pengembangan } \\
\text { karir }\end{array}$ & .958 & 1.271 & & .754 & .452 \\
& $\begin{array}{l}\text { Kompensasi } \\
\text { Finansial }\end{array}$ & .783 & .080 & .573 & 9.785 & .000 \\
& .492 & .074 & .389 & 6.645 & .000 \\
\hline Sumber: Data diolah oleh peneliti, 2019 & & & & &
\end{tabular}

Sebelum menginterpretasikan tabel 9., terlebih dahulu harus mencari berapa nilai dari $t_{\text {tabel. }}$ Cara mencari nilai $t_{\text {tabel }}$ dapat menggunakan rumus $\mathrm{df}=\mathrm{n}-\mathrm{k}-$ 1 (n adalah jumlah responden dan $\mathrm{k}$ adalah jumlah variabel bebas) dengan signifikan 0,05 , maka $\mathrm{df}=121-2-1=118$ dan $\mathrm{t}_{\text {tabel }}=1,980$ atau menggunakan Microsoft Excel dengan formula $=\operatorname{TINV}(0,05,118)$. Adapun rumusan hipotesis dan kriteria pengambilan keputusannya adalah:

\section{Hipotesis 1}

$\mathrm{H}_{0}$ : Pengembangan karir tidak berpengaruh terhadap kepuasan kerja.

$\mathrm{H}_{\mathrm{a}} \quad$ : Pengembangan karir berpengaruh terhadap kepuasan kerja.

Hasil dari tabel IV.17 memperoleh thitung dari pengembangan karir sebesar 9,785 dan $t_{\text {tabel }}$ sebesar 1,980, maka diketahui bahwa $t_{\text {hitung dari pengembangan }}$ karir 9,785 > $\mathrm{t}_{\text {tabel }}$ 1,980 yang artinya pengembangan karir secara signifikan mempengaruhi kepuasan kerja. selanjutnya nilai signifikansi dari pengembangan karir sebesar 0,000, dengan demikian $0,000<0,05$. Dengan demikian, dapat disimpulkan bahwa koefisien adalah signifikan atau $\mathrm{H}_{0}$ ditolak dan $\mathrm{H}_{\mathrm{a}}$ diterima yang artinya bahwa variabel pengembangan karir secara signifikan berpengaruh terhadap kepuasan kerja.

\section{Hipotesis 2}

$\mathrm{H}_{0}$ : Kompensasi finansial tidak berpengaruh terhadap kepuasan kerja.

$\mathrm{H}_{\mathrm{a}} \quad$ : Kompensasi finansial berpengaruh terhadap kepuasan kerja.

Sementara itu, berdasarkan tabel IV.17 dapat diketahui bahwa $t_{\text {hitung }}$ dari kompensasi finansial 6,645 dan $t_{\text {tabel }}$ sebesar 1,980, maka diketahui bahwa thitung 
dari kompensasi finansial sebesar 6,645 $>\mathrm{t}_{\text {tabel }}$ 1,980 yang artinya yang artinya kompensasi finansial secara signifikan mempengaruhi kepuasan kerja. Selanjutnya, nilai signifikansi dari kompensasi finansial sebesar 0,000 dengan demikian, $0,000<0,05$. Dengan demikian, dapat disimpulkan bahwa koefisien adalah signifikan atau $\mathrm{H}_{0}$ ditolak dan $\mathrm{H}_{\mathrm{a}}$ diterima yang artinya bahwa variabel pengembangan karir secara signifikan berpengaruh terhadap kepuasan kerja.

\section{Hasil Uji Kelayakan Model}

Untuk menguji hipotesis ketiga, yaitu apakah model penelitian pengembangan karir dan kompensasi finansial dapat memprediksi kerpuasan kerja karyawan Subdivisi Plate Manufacturing PT Yuasa Battery Indonesia, maka perlu dilakukan uji kelayakan model

\section{Hipotesis 3}

$\mathrm{H}_{0}$ : Pengembangan karir dan kompensasi finansial tidak dapat memprediksi model terhadap kepuasan kerja.

$\mathrm{H}_{\mathrm{a}}$ :Pengembangan karir dan kompensasi finansial dapat memprediksi model terhadap kepuasan kerja.

Dasar dari pengambilan keputusan adalah:

- Jika Fhitung < Ftabel maka Ho diterima.

- Jika Fhitung > Ftabel maka Ho ditolak.

Hasil uji kelayakan model dapat dilihat pada tabel berikut ini:

Tabel 10. Hasil Uji Kelayakan Model

\begin{tabular}{llrrrrr}
\hline \multicolumn{8}{c}{ ANOVA $^{\mathrm{a}}$} \\
\multicolumn{1}{c}{ Model } & & Sum of & & & & \\
\hline 1 & Squares & df & Mean Square & \multicolumn{1}{c}{$\boldsymbol{F}$} & \multicolumn{1}{c}{ Sig. } \\
\hline & Regression & 4213.082 & 2 & 2106.541 & 222.974 & $.000^{\mathrm{b}}$ \\
& Residual & 1114.802 & 118 & 9.447 & & \\
& Total & 5327.884 & 120 & & & \\
\hline
\end{tabular}

a. Dependent Variable: Kepuasan Kerja

b. Predictors: (Constant), Kompensasi Finansial, Pengembangan Karir Sumber: Data diolah oleh peneliti, 2019

Pada tabel 10., Fhitung yang diperoleh sebesar 222.974. Nilai Fhitung 
kemudian dibandingkan dengan nilai Ftabel, didapat Ftabel sebesar 3,07 dengan demikian Fhitung > Ftabel. Signifikasi pada uji kelayakan model sebesar 0,000, dengan demikian $0,000<0.05$. Dapat disimpulkan bahwa model penelitian pengembangan karir dan kompensasi finansial dapat memprediksikan variabel kepuasan kerja karyawan subdivisi plate manufacturing PT Yuasa Battery Indonesia.

\section{Hasil Analisis Koefisien Determinasi (Adjusted $\mathbf{R}^{2}$ )}

Analisis koefisien determinasi digunakan untuk mengukur seberapa besar kemampuan variabel bebas menjelaskan variabel terikat.

Tabel 11. Hasil Analisis Koefisien Determinasi (Adjusted $\mathbf{R}^{\mathbf{2}}$ )

\begin{tabular}{lcccc}
\multicolumn{4}{c}{ Model Summary } \\
\hline Model & $\boldsymbol{R}$ & $\boldsymbol{R}$ Square & $\begin{array}{c}\text { Adjusted } \boldsymbol{R} \\
\text { Square }\end{array}$ & $\begin{array}{c}\text { Std. Error of the } \\
\text { Estimate }\end{array}$ \\
\hline 1 & $.889^{\mathrm{a}}$ & .791 & .787 & 3.074 \\
\hline a. Predictors: (Constant), Pengembangan karir, Kompensasi Finansial \\
b. Dependent Variable: Kepuasan Kerja
\end{tabular}

Sumber: Data diolah oleh peneliti, 2019

Berdasarkan Tabel 11. dapat terlihat bahwa adjusted $R$ square sebesar 0,787 yang artinya kemampuan variabel pengembangan karir dan kompensasi finansial dalam menjelaskan kepuasan kerja sebesar 78,7\%, sedangkan sisanya 21,3\% dijelaskan oleh faktor lain yang tidak diteliti.

\section{KESIMPULAN DAN SARAN}

\section{Kesimpulan}

Berdasarkan penelitian mengenai "pengaruh pengembangan karir dan kompensasi finansial terhadap kepuasan kerja subdivisi plate manufacturing PT Yuasa Battery Indonesia” maka dapat diambil kesimpulan sebagai berikut:

Deskripsi pengembangan karir dan kompensasi finansial terhadap kepuasan kerja subdivisi plate manufacturing PT Yuasa Battery Indonesia, dapat ditarik kesimpulan berdasarkan hasil analisis deskriptif adalah: Pengembangan Karir yang dimiliki karyawan subdivisi plate manufacturing pada PT Yuasa Battery Indonesia tergolong dalam kategori kurang baik; Kompensasi Finansial yang 
dimiliki karyawan subdivisi plate manufacturing pada PT Yuasa Battery Indonesia tergolong dalam kategori kurang layak; Kepuasan kerja yang dimiliki karyawan subdivisi plate manufacturing PT Yuasa Battery Indonesia tergolong dalam kategori rendah.

Pengembangan karir memiliki pengaruh dan signifikan terhadap kepuasan kerja subdivisi plate manufacturing PT Yuasa Battery Indonesia, yang artinya jika pengembangan karir kurang baik maka kepuasan kerja karyawan akan rendah, begitu sebaliknya. Kompensasi finansial memiliki pengaruh dan signifikan terhadap kepuasan kerja subdivisi plate manufacturing PT Yuasa Battery Indonesia, yang artinya jika kompensasi finansial karyawan kurang layak maka tingkat kepuasan kerja karyawan akan rendah, begitu sebaliknya. Pengembangan karir dan kompensasi finansial dapat memprediksi model terhadap kepuasan kerja subdivisi plate manufacturing PT Yuasa Battery Indonesia,

\section{Saran}

Ada beberapa saran yang dapat peneliti sampaikan untuk kemajuan perusahaan,

1. perusahaan meningkatkan kompensasi yang diberikan kepada karyawan dan bila secara finansial memberatkan perusahaan bisa dalam bentuk non finansial seperti penghargaan kepada karyawan berprestasi untuk meningkatkan kinerja atau mengadakan program gathering.

2. Perusahaan mengadakan atau mengirim karyawan untuk mengikuti latihan atau work shop untuk meningkatkan ketrampilan atau keahlian dibidangnya sesuai kebutuhan. Disamping itu ada kejelasan jenjang karir dengan segala syarat yang harus dipenuhi karyawan hal ininuntuk menghindari terjadinya kecemburuan sosial.

\section{DAFTAR PUSTAKA}


Badeni. (2013). Kepemimpinan dan Perilaku Organisasi. Bandung: CV Alfabeta.

Bangun, W. (2012). Manajemen Sumber Daya Manusia. Jakarta: Erlangga.

Boone, L.E. \& David L.K. (2009). Contemporary Busimess: Cengage Learning.

Fathoni, A. (2006). Manajemen Sumber Daya Manusia. Jakarta: Rineka Cipta

Flippo, E.B. (2001). Manajemen Personalia dan Sumber Daya Manusia. Edisi Keenam. Jakarta: Erlangga.

Kadarisman. (2012). Manajemen Pengembangan Sumber Daya Manusia. Jakarta: Rajawali Pers.

Kreitner, R \& Angelo Kinicki. (2008). Organizational Behavior. New York: McGraw-Hill.

Kriswanti. (2017). Pengaruh pengembangan karir dan kompensasi finansial terhadap kinerja pegawai dengan kepuasan kerja sebagai variabel mediasi (Studi empiric pada kantor BBWS Pemali Juana). Semarang. STIE Dharmaputra Semarang.

Kurniawan, Kenny. (2015). Pengaruh pengembangan karir dan kompensasi terhadap kepuasan kerja karyawan di PT Parit Padang Global. Surabaya. Agora Vol. 3, No.2.

Lussier, N. R. (2010). Human Relation in organization. New York: McGraw-Hill.

Mangkuprawira, S. (2002). Manajemen Sumber Daya Manusia Strategi. Jakarta: Ghalia Indonesia.

Mejia, R.G et al. (2007). Managing Human Resources, $5^{\text {th }}$ Edition. New Jersey: Pearson Education.

Nawawi, H. (2008). Manajemen Sumber Daya Manusia Untuk Bisnis Yang Kompetitif. Yogyakarta : Gadjah Mada Univesity Press.

Noe, H, Gerhart \& Wright. (2008). Human Resource Management: Gaining a Competitive Advantage $6^{\text {th }}$ Editions. Singapura: The McGraw-Hill, Inc.

(2010). Manajemen Sumber Daya Manusia. Jakarta: Salemba Empat.

Panggabean, M.S. (2004) Manajemen Sumber Daya Manusia. Bogor: Ghalia Indonesia

Parimita, Widya et al. (2015). Pengaruh Pengembangan Karir dan Motivasi terhadap Kepuasan Kerja Karyawan PT Pos Indonesia (Persero) Bekasi. Jurnal Riset Manajemen Sains Indonesia Vol. 6, No. 1. 
Rivai, V \& Mulyadi, D. (2012). Kepemimpinan dan Perilaku Organisasi, Edisi Ketiga. Jakarta: Rajagrafindo Persada.

Rivai, V. (2011). Manajemen Sumber Daya Manusia Untuk Perusahaan; dari Teori ke Praktik. Jakarta; Raja Grafindo Persada.

Rivai, V \& Segala, E.J. (2009). Manajemen Sumber Daya Manusia Untuk Perusahaan : Dari Teori ke Praktik. Jakarta: RajaGrafindo Persada.

Robbins, S.P. (2001). Perilaku Organisasi Edisi Ke Delapan Jilid 1 \& 2. Jakarta: PT Prihalindo.

Robbins, S.P \& Timothy A Judge. (2009). Organizational Behavior $13^{\text {th }}$ Editions. United States of America: Pearson Prentice Hall.

(2008). Perilaku Organisasi. Jakarta: Salemba Empat.

Sari, Herda Novita. (2015). Pengaruh pengembangan karir terhadap kepuasan kerja karyawan PT Bank Tabungan Negara Kantor Cabang Pekanbaru. Riau. Jom FISIP Vol. 2 No. 1.

Saydam, G. 2000. Manajemen Sumber Daya Manusia. Jakarta: Djambatan.

Waspodo, Agung AWS et al. (2017). The Influence of Compensation, Motivation, and Career Development on Employees Job Satisfaction at PT Nikko Cahaya Electric. Jakarta. Jurnal riset manajemen sains Indonesia Vol. 8, No. 1 
